Proceedings of the Yorkshire Geological and Polytechnic Society

\title{
Notes on the Occurrence of Fossil Fish Remains in the Carboniferous
} Limestone Series of Yorkshire

J W. Davis

Proceedings of the Yorkshire Geological and Polytechnic Society 1882, v.8; p39-63. doi: 10.1144/pygs.8.1.39

$\begin{array}{ll}\begin{array}{l}\text { Email alerting } \\ \text { service }\end{array} & \text { click here to receive free e-mail alerts when new articles cite this article } \\ \begin{array}{l}\text { Permission } \\ \text { request }\end{array} & \text { click here to seek permission to re-use all or part of this article } \\ \text { Subscribe } & \begin{array}{l}\text { click here to subscribe to Proceedings of the Yorkshire Geological and } \\ \text { Polytechnic Society or the Lyell Collection }\end{array}\end{array}$

\section{Notes}


NOTES ON THE OCCURRENCE OF FOSSIL FISH REMAINS IN THE CARBONIFEROUS LIMESTONE SERIES OF YORKSHIRE.

BY JAMES W. DAVIS, F.G.S.

The fish remains of the Mountain Limestone of Yorkshire are not numerous, neither are they found in a great number of localities. If the great area of the western and northern portions of the county be taken into consideration, which are more or less occupied by the Mountain Limestone, extending from Clitheroe and Slaidburn, Thornton, Skipton, to Greenhow Hill in the south, to the limits of the county westwards and northwards, and that in all these localities, and very many others, the rock is expcsed and excavated for commercial and agricultural purposes, in quarries of enormous extent, there can remain but one conclusion, that whilst these rocks are replete with fossil mollusca, corals and encrinites there appears to have been a most remarkable absence of fishes in the seas of that period. The non-discovery may be attributed to a want of interest in this branch of palæontology, on the part of collectors, who may perhaps have been more deeply interested in the collection of the beautiful and perfectly preserved specimens of fossil brachiopods, corals and others which abound in many localities, largely quarried, whilst the less known and infinitely rarer remains of fishes have been neglected. Notwithstanding this disadvantage there seems to be little doubt that the absolute sterility of most localities must be attributed to the absence of fossil remains rather that than the need of collectors, and we are driven to the conclusion that, only in few localities and on special horizons have fishes been preserved in a fossil state. The reason for this peculiar arrangement opens a wide field for most interestting speculation. It would appear improbable that during the deposition of the strata containing fish-remains there was an abundant ichthyic fauna in the carboniferous seas, extending only over a comparitively limited area, and existing only for a sufficient period to accumulate, in most cases, a very thin stratum of lime- 
stone in which the fossils are preserved, and that during the longer intervals when the intervening thickness of limestone was deposited, there was an almost total absence of fishes in the sea. It has already been observed that the limestone is generally a homogeneous substance of a more or less crystalline structure, but the exploration of the present beds of some of the deep seas where chalk or limestone is in process of deposition has proved that side by side with the foraminifera which secrete calcareous substances, there are others which have a more or less siliceous skeleton and that the latter constitutes a portion of the substance forming the sea bottom. One of the peculiarities in connection with the great aggregation of fish-remains in the Red Beds of Wensleydale is, that the beds are extremely cherty, masses of nodular chert extend in horizontal layers in close proximity with the fish-beds. The method by which the nodules and beds of chert have been separated is not understood; it is possible that the presence of submarine thermal springs, due to volcanic action, may have something to do with the aggregation of the silica to form the cherty or flinty masses. If such be the case, it might be equally probable that the ebullition of water, charged with perhaps poisonous ingredients, would result in the destruction of large numbers of fishes, and in this way the fish-beds may have originated. Except on some hypothesis such as this, it is difficult to conceive a good reason for the occurrence of immense numbers of fish-remains on definite horizons of small thickness, and their almost total absence throughout great thicknesses of intermediate limestone.

Notwithstanding the extreme localization of the beds containing fish-remains there is no reason to complain of the numbers of either specimens or species in localities where they do occur and have been carefully collected, but as will be observed further on, the characteristics of the Yorkshire Limestone fishes are peculiar. In many respects they are distinguished from those, either of the limestone of other localities of the British Islands, or of the coal measures which succeeded them. 
Amongst the more frequent examples of ichthyodorulites found in the Mountain Limestone of Bristol, in which locality numerous specimens have been discovered, are the spines and teeth of large predacious fishes allied to the sharks now living. Some of the fish-spines are of immense size. An example in the collection of Earl Ducie at Tortworth Court, which is imperfect at the base, was probably, three feet in length. The fish to which it belonged, judging by comparison with living forms, must have been nearly forty feet in length. Many other genera and species of fishes which were possessed of large fin-defences occur in the limestone on the banks of the Avon.

The limestone at Armagh, in Ireland, contains a large uumber of teeth, which from their peculiar angular margins and flat surfaces, have evidently occupied the mouth of the fish with a flat pavement-like arrangement. This form of dentition is admirably adapted for preying on animals enclosed by hard shells like the mollusca. Perhaps the most characteristic teeth of the Yorkshire Limestones are those of Petalorhynchus and Pristodus, the dentition of the latter resembles that of the peculiar fish Diodon, now living in the seas under the warm rays of the tropical sun. In Diodon, each jaw is occupied by a single tooth which extends over the palate as well as envelopes the outer margins of the jaws.

Besides the fishes mentioned, which appear to be localized and peculiar to certain districts, there are many others which are common to all of them. Groups represented by the twisted teeth of Cochliodus, the pavement-like teeth of Psammodus, and the sharppointed, shark-like teeth of Cladodus, are found in greater or less abundance in all the localities where fossil fishes have been discovered.

The larger proportion of the fish-remains of the Carboniferous Limestone appear to be restricted to the formation; they are not found in the earlier strata of the Old Red Sandstone or the still 
older Silurians. The fishes found in the Old Red are comprised in the externally armour-plated fishes of which Coccosteus may be taken as the type, and the thick, enamel-scaled fishes represented by Cheirolepis, Acanthodes and Osteolepis, all of which are ganoids. In the Mountain Limestone, Ganoid fishes are almost entirely absent, being represented only by a few plates of Colacanthus from Armagh ; unless it shall be found that the variousshaped pustulate plates of Oracanthus represent the external armour of a fish allied to Coccosteus.

The great Elasmobranch fishes, armed with dorsal fin-spines of great power, for either offence or defence, became of great importance during the limestone era, they are represented in earlier formations only by the small spines of Onchus in the Silurians. In later formations some of the Limestone Elasmobranchs are represented by descendants in the genus Ctenacanthus; others may also possess characters more or less common to the genera of both formations In the shales of the coal measures, ganoid fishes of very large size such as Rhizodus and Megalichthys become of frequent occurrence, the rare Cœlacanthus of the limestone, in the Cannel coal becomes an extremely abundant genus, and several placoid fishes possessing characteristics quite different from those of the Mountain Limestone becomes tolerably abundant. The Acanthodians, which were common in the Old Red Sandstone strata, but absent from the limestone, again put in an appearance in the coal measures. The great majority of the limestone fishes, however, are not found in the coal measures, the great group of Copodonts and Psammodonts, the Cochliodonts and the last remnant of the Coccostean group, if Oracanthus be such, have all disappeared prior to the deposition of the coal measures.

It must not of necessity be supposed that the changes indicated above were of univeral significance, it is far more probable that they were due to circumstances more or less localized in extent. The Carboniferous Limestone is a deep water formation, 
and the fish-remains contained in its strata were doubtless those of the fishes which inhabited those deep waters, but the Old Red Sandstone formations were accumulated in much shallower water, probably in many cases formed the shore during the deposition of the Limestone in the deep waters beyond, the fishes found fossil in those beds, may naturally be expected to differ in character from those of the deep water. The Coal measures again are the result of deposits of sand and mud brought from the land by streams either to an estuary of the sea or inland lakes, in either case, the piscine fauna may be expected to exhibit peculiarities totally different to those of the fauna of the Limestone.

It is proposed after giving the list of fishes found in the Yorkshire Limestone series which immediately follows, to consider the relationship they appear to possess with other fossil forms, and their zoological position with regard to allied fishes now existing, and to draw such inferences therefrom as may seem desirable.

Cladacanthus paradoxus, Agass.

Physonemus arcuatus, Agass.

Cladodus mirabilis, Agass. , striatus, Agass.

" basalis, Agass.

" Hornei, Davis. mucronatus, Davis.

Pristicladodus dentatus, McCoy. , Goughi, McCoy. ...

Glyphanodus tenuis, Davis. ... Orodus ramosus, Agass ...

"Reedi, Davis, ... Diclitodus scitulus, Davis.

Cochliodus contortus, Agass.

Deltodus aliformis, Agass.

Deltoptychius acutus, Agass.

Psephodus magnus, Agass.

Poecilodus Jonesii, Agass.

", sp., nov.

Pleurodus Woodi, Davis.

Psammodus rugosus, Agass.

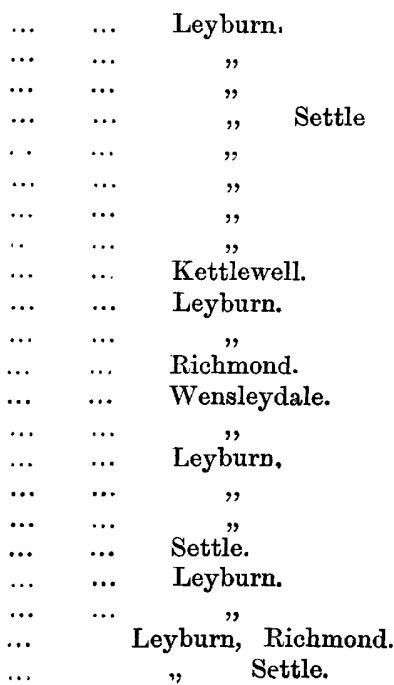




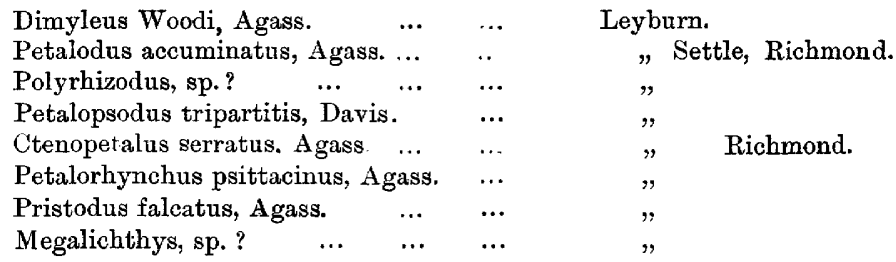

The whole of the fish remains enumerated above are comprised in the sub-class, Palceichthytes as defined by Dr. Gunther. The sub-class includes two orders, the Chondropterygii and the Ganoidei. The latter is equivalent to Prof. Huxley's Ganoidei and Dipnoi, whilst the former comprises the Elasmobranchii of Prof. Huxley's classification and includes the sharks, rays, and chimeras. The order Chondropterygii is divided into two sub-orders: Plagiostomata, comprising the sharks and rays, and the Holocephala, the chimeras. The Elasmobranch fishes of the Mountain Limestone are all included in the Sub-order Plagiostomata. The remains of these fishes which have been preserved are always in a disintegrated condition and consist of detached teeth or spines. A slight consideration of the anatomy of an existing shark will at once explain the reasons why this is so. The framework of a shark is cartilaginous; the mandibles, skull, supports for the fins, \&c. are each unossified, though well developed; and the vertebræ are also in many cases cartilaginous though various modifications occur. In some there is a slight ring of bone imbedded in the cartilage, in others the whole of the vertebra is ossified. The vertebræ of the plagiostomous fishes whose remains are found in the Carboniferous Limestone appear to have been entirely cartilaginous, for hitherto no trace has been found of their preservation. The only parts of the fish which have been preserved are the teeth, the spines which occupied positions in front of the dorsal or pectoral fins, and occasionally patches of the dermal covering like shagreen. The organs on which, since the researches of Johannes Müller, modern classification has beon based-the heart, the spiral intestine and the 
optic nerves, have entirely disappeared, and it is only by comparison of the parts preserved fossil with similar ones in existing fishes that we are enabled to affirm that as in the recent fish, the teeth, \&c. bear funcional relatiouship with the soft parts of the fish, so in the fossil state similar teeth must have borne a corresponding relationship with the parts of the fish which have disappeared. That the remains which are preserved should be mixed up in almost inextricable confusion is not remarkable when it is remembered that after the cartilaginous portions of the fish, which connect its several hard parts, have become decayed, the latter, each separated from the other, are liable to be washed hither and thither by every tide or current, and to become widely separated and intermixed with remains of other fishes so that it is an occurrence of extreme varity to find even the teeth of a fish in so happy juxtaposition that they can be identified as pertaining to the same individual.

In attempting to trace the affinities and relationships of fossil fishes to recent forms the divergence between them is in some cases apparently slight, whilst in others, characters are developed which, unless they be regarded as connecting links between an older fauna and the present one, are inexplicable. So far as there is any evidence at present known, the Lower Silurian and all preceeding formations are devoid of fish remains; from which it may be inferred, that the advent of fishes took place during the deposition of the Upper Silurian Strata. During the succeeding Devonian and Old Red Sandstone age, immense numbers of fishes swam in the seas. In size they were little inferior and in structure they were scarcely less highly organized than the fishes inhabiting the waters at the present day. Notwithstanding: this, they present many peculiarities which have long since disappeared and been replaced in following ages by others, again to flourish for a while and in their turn disappear. The fishes of the earlier formation whilst perfectly organized present a much simpler fauna than in succeeding ones, and whilst the 
number of individuals may have been as large as during any succeeding age, the diversity of form, which for convenience of reference we designate by the terms genera, and species, has greatly increased; and at the present time the repeated divergence of the original forms through succeeding ages has produced an almost endless variety, infinitely greater than at any previous portion of the history of the world. It is more than probable that this great variety of forms has been produced by repeated slight differentiations from the parent stock, which, rendering the offspring better capable of adaptation to an altered environment, or presenting some feature more readily transmitted has gradually modified the species until all trace of relationship with its first parents is lost. It is for this reason, amongst others, that the study of fossil forms is essential to a thorough knowledge of existing fishes; the characters found in different families of the latter, now quite distinct, were originally combined or blended in the earlier fishes, so that the fossil fishes form links in an almost endless chain, which renders their study of intense interest to the modern biologist. The imperfections in this developmental chain are great; but every new addition to the knowledge of fossil ichthyology, derived from new or well preserved specimens, serves to throw additional light on the subject and to render a complete elucidation of the relationships of living species more possible.

Until a comparatively modern epoch the group of fishes with a bony skeleton, the Teleostei, which form by far the largest portion of existing fishes, is not represented in a fossil state, their first appearance being during the deposition of the chalk. The Plagiostomata or sharks have been represented from the earliest times to the present. Traces of this group are first observed in the Upper Silurian rocks of Ludlow, and they have continued to exist in greater or less profusion through every succeeding geological epoch. In the Carboniferous series of rocks the number of species already discovered is very large, and comprises a con- 
siderable variety of plagiostomous fishes which have since disappeared. Prof. Agassiz considered that a large proportion of the Carboniferous fishes bore a greater resemblance to the Cestracion,or Port Jackson Shark, than to any other existing genus; the latter is represented by one or two existing species only, and appears from its comparatively small numbers and localized extent to be almost on the point of extinction. An important characteristic of the sharks of the older geological ages lies in their possessing, to a much larger extent than at present, large fin-spines, in many instances highly ornamented.

The Ganoidei, which comprises an enormous assemblage and great variety of fishes in the ancient geological periods, is now reduced to a comparatively small number of species inhabiting the rivers of America and Africa, and the sturgeons which are marine. The typical ganoid, represented by the Garpike (Lepidosteus) of the American rivers, or the fossil Megalichthys, is covered with a coat of rhomboidal, thick, bony scales, with an enamelled surface. There are however, many exceptions to this character, and the living Amia of the American lakes, covered with thin imbricated scales, is devoid of enamel, they are of small size, very similar to some of the bony fishes.

The groups of fossil fishes found in the Yorkshire Limestone Series included in the sub-order Plagiostomata are the following.

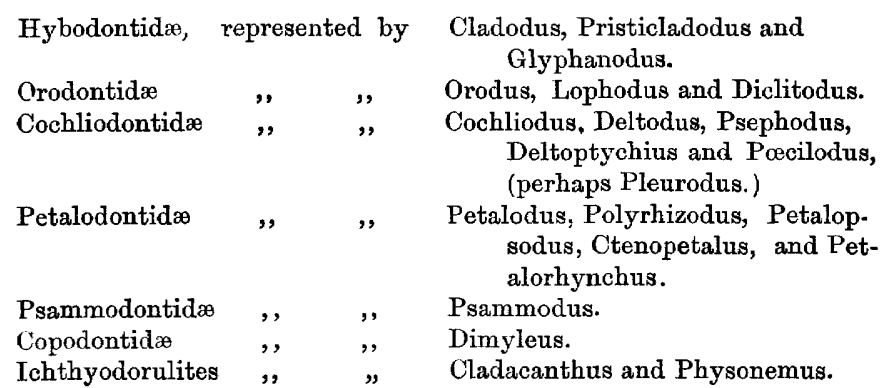

Besides these, the teeth of the genus Pristodus, which cannot be included with any of the above groups; but whose affinities 
seem to lie in the direction of the Plagistomata, is very abundant in the upper bed of the series and is peculiar to this district.

In other localities the group Hybodontidee is represented by several genera of spines which bear a greater or less resemblance to the Hybodus of the Lias. Amongst the most formidable of these are the spines of Ctenacanthus and associated with them the teeth called Cladodus. It has been thought probable, from the spines of Ctenacanthus and the teeth of Cladodus occuring together with considerable frequency, that they may have been co-existent in the same fishes. It is well known that the spines of Hybodus of the Lias were associated with teeth to which Cladodus bear some resemblance. The latter differ from Hybodus in the cusps produced from the surface of the crown being longer and sharply pointed; in other respects they are similar. A peculiar circumstance in connection with this group in the Yorkshire Limestone is that, whilst the teeth of Cladodus are represented by five or six species, some of which, like C. straitus, are very common; there has hitherto been no specimens of Ctenacanthus discovered. The teeth occur in the thick-bedded limestone of Settle and Giggleswick, examples from the quarries in the neighbourhood may be seen in the Museum of the Grammar School of the latter place; they also frequently occur in some of the thin limestones in Wensleydale, comprised in the Yoredale series of Prof. Phillips, and in the limestone quarries in the neighbourhood of Richmond, but in none of these localities have the spines of Ctenacanthus been discovered. Considering the large numbers of teeth of Cladodus which have been found, and the absence, hitherto, of any evidence of spines, even approaching in character to Ctenacanthus, negative evidence of considerable weight is afforded that the two genera were not so closely related as has been suggested, or at any rate, that the teeth of Cladodus may have belonged to a predaceous fish unprotected by fin-rays, in the Carboniferous area in this district.

The genius Pristicladodus is in many respects similar to 
Cladodus, it is a thicker and stronger tooth with only one lateral cusp on each side the large central one. The name was given originally by Prof. M. Coy to teeth from the Limestone of Derbyshire. Glyphanodus is a very peculiar species, the teeth are excessively thin and compressed, the crown consisting of a single median cone with a chisel-like edge, sharp and smooth. The base descends co-extensively with the crown and resembles that of the Petalodonts more than Cladodus which usually extends in a more or less horizontal direction backwards; the crown of the tooth is however, much more closely related to Cladodus than the Petalodonts, possessing characters which would associate it with both genera it may perhaps be looked upon as a connecting link between the two. It has been found only in Yorkshire.

The teeth comprised in the group Orodontidce have a very wide distribution both in the British Islands, on the continent of Europe, and in America. Those found in Yorkshire comprising two species of Orodus are small and comparatively rare; there is also one species of Lophodus and a new genus Diclitodus. The latter has only been found in Yorkshire, it differs from the genus Orodus in possessing two equal cones raised from the crown; in other respects it bears a considerable likeness to the Orodonts and has been placed provisionally amongst them.

The Orodonts in the Limestones of Bristol and Armagh are very much larger in size than the Yorkshire ones but it is rarely that two or more teeth are found in juxtaposition though two or three instances have occurred in which three or four teeth have been connected together in such a manner as to leave no doubt that they still retained a natural position. Though examples are rare in this country of specimens which exhibit the arrangement of the teeth on the jaws, American palæontologists have discovered at Osage, County Kansas in America, an extremely well preserved series of teeth which illustrate the whole dental arrangement. The teeth are from the coal measures and are described in "Palœontology of Illinois" Vol. VI. p. 311, by 
Messrs. St. John and Worthen. Though very closely related to Orodus the authors consider that minor differences are sufficiently distinctive to form the new genus Agassizodus for the accommodation of the specimens. About four hundred and fifty to five hundred teeth comprised the whole of the left ramus of the lower jaw and a portion of the right one. In their description of this remarkable specimen the authors state that "the articular extremities of the jaw are not preserved, though fragments of the substance of the cartilage are scattered through the rock mass upon which the teeth are imbedded. These cartilages were doubtless comparatively thin, the outer and inner folds giving way to the pressure which flattened the rami, as shewn in the present condition. The teeth are disposed in serial rows having a convoluted inrollment from the inner to the outer border, and gradually increasing in size from the posterior extremity to the row of large median teeth, anterior to which the rows as regularly diminish in size towards the symphysis," the posterior portion of the jaw has six to nine rows of teeth similar in form to, but of smaller size than the teeth of the median portion. The middle portion of the ramus is occupied by a row of proportionately very large teeth which differ from the posterior teeth in having the crown produced intoa strong, obtusely conical excentric prominence which culminates at a point more or less posterior of the middle of the tooth, whilst the posterior teeth are devoid of any defined median keel. The anterior portions of the teeth are very similar to those situated posteriorly of the median row. There are eight to nine rows, and contrary to the posterior ones they gradually diminish in size anteriorly as they approach the symphysis of the jaw. In the extreme anterior rows the teeth assume considerable diversity of form, and there are a number of minute, nearly circular teeth which exhibit in the form of the crown, and its sculpturing a strong likeness to Petrodus. "Generally considered, the teeth present the closest affinities with Orodus Ag., a group prevalent in the Lower Carboniferous formation." But the present 
group of teeth is distinguished by the prevailing prominence of the buttressed condition of the anterior coronal borders, and the relative uniformity or evenness of the posterior face, besides the relatively fewer rows of acuminate teeth, as inferred from this feature being so prevalent in all collections of Orodi, while the linear forms are least commonly met with. The authors also state that in addition to the teeth and pieces of cartilaginous matter which appear to have formed the supports of the jaws, there were a number of exceedingly small bodies "irregularly circular in outline, with a depressed convex coronal portion, which rises into an eccentric acumination or transverse ridge along one side, and delicately sculptured with irregular carina radiating from the apex towards the marginal borders." Below they are concave. No two specimens appear to be exactly alike, though they have a general resemblance, especially in the dark horny luster of the enameled crown, by which they are readily distinguished from the teeth with which they are associated. It seems not improbable that these minute bodies constituted part of the dermal covering or shagreen of the fish.

The description of the fossil Agassizodus from the Kansas coal measures bears a close resemblance to the description given by Prof. Owen of the dentition of the modern Cestracion, and as the subject forms one of the few rare instances in which one of the earlier plagiostomous fossil fishes can be reliably compared with an existing form, I venture to give Prof. Owen's description as follows, "The teeth at the anterior part of the jaws are the smallest; they present a transverse, sub-compressed, conical figure, with the apex produced into a sharp point; these points are worn away from the used teeth at the anterior and outer parts of the jaw, but are strongly marked in those which still lie below the margin. There are six subvertical rows of these small cuspidate teeth on each side of the jaw, together with a median row close to the symphyseal line; and from twelve to fourteen teeth to a row. Behind the cuspidate teeth, the five consecutive rows of 
teeth progressively increase in all their dimensions, but principally in their antero-posterior extent; the sharp point is converted into a longitudinal ridge, traversing a convex crushing surface, and the ridge itself disappears in the largest teeth. As the teeth increase in size, they diminish in number in each row; the series of the largest teeth includes from six to seven in the upper and from seven to eight in the lower jaw Behind this row, the teeth, although preserving their form as crushing instruments, progressively diminish in size; while at the same time the number comprised in each row decreases. From the oblique and apparently spiral disposition of the rows of teeth, their symmetrical arrangement on the opposite sides of the jaw, and their graduated diversity of form, they constitute the most elegant tesselated covering of the jaws which is to be met with in the whole class of fishes" (Odontography, page 51). A comparison of the two forms shews how small is the difference between them, both in the characters of the teeth and in the form of arrangement. The arrangement of the fossil is almost exactly similar to the appearance which would be presented by the teeth of Cestracion if they were spread out and compressed. The most striking difference between them lies in the more obtuse arrangement of the anterior portion of the jaw of Agassizodus. It may be naturally inferred that A gassizodus and the Orodonts generally, like the living Cestracion, fed on Molluses and other animals which were protected by, or encased in hard shelly coverings, the arrangement of the flat crushing teeth admirably adapting them to break or crush the hard substances in order to extract the animal. The size of the fossil Orodonts may be inferred from a comparison with the existing species. The Cestracion found off the the shores of Australia is two to three feet in length and the jaws from three to five inches, the jaws of Orodus ramosus were probably three feet in length, and this would give the length of the fish at about thirty feet, a truly formidable creature.

The modern Cestracian is possessed of two defensive spines, 
one before each dorsal fin, but there is no evidence to shew whether the fossil Orodonts had such spines; the discoveries of further examples may serve at some future time to shew whether they had or not: so far as the evidence of the specimens found in Yorkshire goes, it would seem to indicate that they were not so defended.

Several species of the genus Lophodus have been found in the upper beds of limestone in Wensleydale. The genus was originated by M. Rowanowsky, in 1864 (" Bull. de la Soc. Imperial des Naturalists de Moscow," p. 160), and embraces the teeth of fishes which are closely allied with Orodus but present several features which had hitherto been considered to be characteristic of Helodus. Lophodus comprises teeth in which the crown of the tooth is more or less conical in outline with a corresponding concavity of the base, whilst in the teeth of Helodus there is no such concavity, and the crown, somewhat expanded laterally over the base, rises up from all sides to the apex. The base of the crown in Lophodus is contracted on each side and curved inwards to the root.

The Cochliodontidæ are well represented in the Yorkshire limestones, so far as number of genera goes, but the number of specimens found have not been very great. The genera comprise species in Cochliodus, Deltodus, Deltoptychius, Psephodus and Pocilodus; they differ very considerably from each in many minor peculiarities, but they agree in others of greater importance. The distinguishing characteristic of the group is, that the teeth "grow or increase in size, not as in most fishes by the old and worn teeth being replaced from behind or below, but by continuous or repeated additions to the inner or posterior margin of the surface of the tooth, so that the same tooth is always increasing in size with the growth of the fish, and assumes an inrolled or convoluted form. An analogue of this pecular growth is seen in that of the testaceous covering of the mollusca, which though it assumes a wonderful variety of forms, increases in size 
by the addition of repeated layers to the open margin of the shell."* The genera Cochliodus, Deltodus and Deltoptychius exhibit a distinctly inrolled appearance in a transverse section, whilst Psephodus and Pœcilodus are flatter and increase in size by the radial expansion of the triturating surface. Hitherto, the complete dentition of any member of the group has not been found, but specimens of several of the genera shew that there were three teeth on each jaw ; those in front which approached and joined at the symphysis of the jaw were the smallest, and the second and third pairs increased in size backwards. Those situated most posteriorly are expanded so as to form a wide, more or less convex surface, admirably adapted for crushing and triturating vegetable substances for food, which in all probability formed the principal part of their sustenance. The teeth were attached and partially imbedded in a strong cartilaginous jaw, which possibly extend inwards as to form a palate to which other teeth may have been attached. That teeth similar to those hitherto named Helo dus may have occupied the central portion of the palate, is rendered probable by the discovery in some of the American strata of specimens of Cochliodus and Helodus in close apparent relationship, though the specimens found in this country have not indicated such a combination.

As already stated, the teeth of Cochliodus have a distinctly inrolled or helicine configuration whilst those of Psephodus are much flatter and very slightly curved. The latter vary greatly in size, as well as to a smaller extent, in form. The teeth of Cochliodus have been found not only connected together but the teeth of the two rami of the jaws united by their cartilaginous supports; the teeth of the Psephodus, however, have not been discovered so united, but their arrangement has been proved to be similar to those of Cochliodus by the peculiarly concave under surface. If one of the largest teeth be examined it will be found that the widest posterior edge is rounded, whilst the opposite edge

* Proc. Roy. Soc. Dublin, New Ser. Vol. I., p. 415. 
of the tooth is more or less straight and rectangular, corresponding with this arrangement of the crown, the under surface, which was attached to the jaw, is seen to be concave, the concavity forming a channel or grove, widest at the rounded posterior extremity of the tooth, and diminishing in diameter as it approaches the straight edge. Median teeth may be selected which exhibit a similiar decrease from the back towards the front of the tooth in the channelled inferior surface whilst both margins are more or less straight. The widest end is equal in diameter to the narrowest of the previous tooth, and it diminishes forwards and is connected with a third and still smaller tooth which occupies the space between the median and the sympysis of the two rami composing the jaw. The inferior channel on the third tooth diminishes still more in diameter, and near the symphysis is almost attenuated to a point. In each tooth there is the characteristic convolution. One or two specimens have been discovered with long, narrow teeth attached in front of the teeth on each side the symphysis more or less resembling those called Helodus; it appears probable that these were attached in front of the anterior pair of teeth, which are small and narrow, in order to seize and secure their prey with greater facility ; it is also possible that there may have been other smaller teeth distributed over the median portion of the palate.

The teeth of the other genera, Deltodus, Deltoptychius and Pocilodus appear to have been arranged with modifications to suit their several peculiarities in form, in approximately close relationship with those already described. For the most part they had three teeth increasing in size backwards, as indicated by the channelled surface attached to the cartilaginous jaw, but it is probable that the teeth of the upper jaw of Deltodus and Deltoptychius existed singly, in this respect approaching the arrangement in the jaws of Ceratodus. The teeth in both jaws of Precilodus may have been single.

The Cocbliodonts have been regarded by Prof. Owen and 
others as based on the type of the modern Cestracion or Port Jackson shark, differing from it, however, in possessing few and large teeth in place of a greater number of small ones. Prof Agassiz in the third volume of his Poisson's Fossiles, p. 113, regards Cochliodus as nedrly related to Ceratodus; and considers that the relationship proves that Ceratodus is a plagiostomous shark, both being closely related to the genus Cestracion. Since Prof. Agassiz penned his description, an existing representative of the Ceratodus has been discovered in the mud-fish of Australia, whose dentition is in every respect similar to the fossils described by Prof. Agassiz. The relationship of the living fish is proved to be with the Ganoids, and it is not improbable that the Cochliodonts of the Limestone Formations may eventually be found to be much more closely related to the Ceratodus than to the Cestracionts. The dentition of Orodus and the American genus Agassizodus have been shewn to be very closely related to the living Cestracion; they were co-existent with the Cochliodonts, and it is extremely improbable that they were closely related ; in arrangement and adaptation for feeding they are quite different from each other, the Cochliodonts for vegetable feeding and the Cestracionts to prey on Mollusca, \&c.

The teeth of the Pleurodus Ag. occur in the Limestone in Wensleydale with considerable frequence. They are small, and in all probability are a different species to those found in the coal measures. Though this genus possessed a cartilaginous skeleton, its remains have been discovered in the shales of the coal measures at Newsham in Northumberland, and in those of the West Riding. of Yorkshire, so well preserved that the form of the fish could be ascertained. It was four inches to a foot in length, having a deeply rounded and flat body with a spine in front of the dorsal fin immediately behind the occiput about one third the length of the body, one half the length of the spine was probably buried in the integuments of the fish. In the Newsham specimen the position of the spine and the form of the fish are clearly indicated by the expanse of chagrin or dermal tubercles which has remained 
quietly in position; at the anterior extremity ten or twelve teeth indicate the position of the head. Supposing the number of teeth to have been twelve, there would be three to each ramus of the jaw, which is the same number as in the Cochliorlonts. The teeth of Pleurodus are not unlike those of Pocilodus in form, and surface configuration, and it is within the range of possibility that there may be some relationship between the members of the Cochliodont group and Pleurodus, though it may be advisable to withhold a detailed expression of opinion until more extended observations shall have been made.

The representative of the Psammodontidæ occurring in Yorkshire are not numerous, and are small compared with those of Bristol and Armagh. They possess the usual characteristics of the group, and formed a flat pavement-like arrangement in the mouth admirably adapted for crushing the hard coatings of testaceous animals. Prof. de Koninck in his description of the Fossil Fauna of Carboniferous Limestone of Belgium, has suggested that the teeth were arranged so as to cover the whole of the palatal surface of the mouth; the square massive teeth being joined at their edges, and having on each side and in front smaller teeth, in some cases somewhat triangular in outline, to fill up the rounded conformation of the jaws.

Associated with the Psammodonts are smaller teeth, similar to them in being flat on the surface, but dissimilar in other respects. They were named by Prof. Agassiz, but not described, as Dimyleus Woodi, from specimens contributed by the late Mr. Wood of Richmond in Yorkshire, to the Enniskillen collection. At Armagh many other genera of fish-teeth have been found, which closely approximate with those of Dimyleus found in Wensleydale. A careful study of the whole group shows that they are distinct from the Psammodont family. They have therefore been grouped together as a distinct family, Copodus being regarded as the typical genus, they are termed the Copodontidie.

Perluaps the most remarkable group of fish-remains found in 
the Yorkshire Limestone is comprised in the Petalodontidæ. The group was instituted by Messrs. Newberry and Worthen (Geology and Palæontology of Illinois, vol. ii, p. 31 ), and embraces several genera of fishes known only by their teeth, and so far as at present discovered, confined to the Carboniferous series of rocks. The genera which occur in this county are Petalodus, Agass; Petalopsodus, Davis; Polyrhizodus, McCoy; Ctenopetalus, Agass; and Petalorhynchus, Agass.

The genus Petalodus is represented by the well-known species Hastingsiæ and acuminatus. The latter is fairly abundant and frequently of large size, but otherwise the genus does not offer any features of peculiar interest. Polyrhizodus is represented by only one small and very rare species. This genus frequently occurs in the Limestone of Ireland, and appears to be of sufficiently diversified and well defined character to necessitate the formation of at least six species. The teeth are in many respects similar to those of Petalodus. The strong, well-developed crown with a sharp cutting-edge is equally characteristic of the two genera; the principal difference consists in the formation of the basal portion which was inserted in the jaw of the fish; in Petalodus the base is composed of a single massive root, whilst in Polyrhizodus, as implied in the name, the root is divided into a number of radicals or rootlets, varying in number from four or five, to sixteen or twenty. This character of the root of Polyrhizodus is very puculiar, and does not occur in any other group of fishes, either recent or fossil. The teeth of most of the Plagiostomous fishes are simply attached to the jaw by their under surface in a somewhat loose manner, and as might be suppused, not being firmly implanted in the jaw, but only on it, they are easily displaced. To compensate for this liability to loss, the fishes are provided with several rows or series of teeth, which until required, are arranged on the inner side of the jaw, their sharp edges pointing towards the palate. On the displacement or breakage of the teeth in active use, they are replaced by others from the reserve; this 
character obtains in all the Squali or sharks properly so called. In other groups with a flat and crushing dental arrangement, the old teeth are replaced by new ones which grow underneath them, or like the Cochliodonts, the old portion becomes inrolled on the jaw and a new surface is produced by additions to its lateral edges as already explained. The Petalodonts were very differently attached to the jaw; a strong and deeply-imbedded attachment to the jaw gave them a solidity more analogous to some of the Teleosteans, as for example, Sargus, or the higher vertebrates, than to the sharks, and in this respect the genus Polyrhizodus is more distinguished than its fellows by having the roots divided, and by that means being still more firmly attached to the jaw.

The genera Ctenopetalus, Ag., and Petalopsodus, Davis, are distinguished, the first by its serrated or crenated cutting surface, and the latter by having the coronal edge divided into three distinct and almost equal parts, each rising to a finely pointed apex. The root is not divided. The remaining representative of the group, the Petalorhynchus, Agassiz, is much the most abundant and has been found in large numbers. It is also very fortunate that several specimens have been discovered which throw considerable light on the general dentition of the genus. It is now known that the teeth were arranged in a semicircle conforming to the shape of the jaw in which their long roots were deeply implanted. The root in the older teeth is frequently four times the depth of the height of the crown. The crown has the usual Petalodont character, except that its central portion is produced and pointed, and is slightly bent inwards so as to resemble the pointed beak of a parrot. One central tooth was implanted on the symphysis of the two rami of the jaw, and on each side there extended three others, making a total of seven to each jaw. Specimens have also been found shewing how the teeth are replaced by successive larger growths, as the mouths of the fishes has increased in size. From these it appears that originally there was a single row of small teeth extending along the surface of each jaw, that, as these 
become worn and the fish increased in size, they were replaced by a set of larger teeth from the inside of the mouth, somewhat similarly to the increase in the sharks, except that the earlier row of teeth instead of becoming detached, adhered to the second or new row, and becoming firmly cemented to them served to strengthen and support them. In this way successive additions were repeatedly made, each additional row by its increase in laternal extent as well as in length being proportionate to the increased growth of the jaw. Specimens have been found with five such rows, all firmly cemented and adhering to each other.

The peculiar constitution of the jaw and teeth of Petalorhynchus with the median teeth over the symphysis of the jaw is aberrant from the usual type of the Selachians, and it has to this extent some affinity with the Rays. Messrs. Hancock and Atthey have pointed out the relationship of Climaxodus, McCoy, and Janassa, Münster, in a paper in the "Natural History transactions of Northumberland and Durham, vol. iii., pt. II., p. 330." The arrangement of the teeth of those fishes is very similiar to that of Petalorhynchus, they extend, however considerably more in a horizontal direction, over the palate of the mouth, and in addition to the sharp cutting-edge of the extremity of the tooth, the crown was developed so as to form crushing or triturating surfaces. The authors after a minute description of the specimens arrive at the conclusion that Janassa, Münster, approaches somewhat in character to Myliobates of the newer formations, which have a broad tooth occupying the median portion of the mouth with three rows of smaller teeth on each side extending from the extremity of the jaws inwards over the palate. Should this relationship be established and confirmed by the discovery of intermediate species, an interesting evolutional series may be traced from the Petalodonts of the Lower Carboniferous Limestone, through Chinaxodus of the upper beds of that series, the Janassa of the Permians, to the Myliobates of the newer formations to the members of that genus which still exist in the seas of the present time. 
Before leaving the consideration of the relations of the Petalodont family to other groups of fossil or living fishes, it may be worth while to note the somewhat peculiar resemblance possessed by some members of the genus Sargus, at present existing in the warmer sub-tropical seas. Taking as an example Sargus Rondeletii, Cuv. and Val., the teeth present an extremely inter esting arrangement. Along the anterior extremity of each ramus of the jaw there are four teeth, deeply rooted or implanted in the strong bony framework of the jaw; the portion of the teeth forming the root, and extending some distance beyond the surface of the jaw, is broad antero-posteriorly and somewhat contracted laterally; nearer the apex, however, the tooth becomes laterally expanded, spreading out into a spatulate concavo-convex crown, terminating in a thin straight cutting edge, with highly polished enamel surface and very sharp. The largest teeth are on each side the symphysis of the two rami, and occupy the central portion of the jaw, those on each side decreasing in size backwards, the posterior teeth being less than half the length or breadth of those in front but still preserving the same characters. The resemblance to the Petalodonts is probably merely an accidental one. They differ in the arrangement of the median teeth which are separated by the simphysis of the jaw, and do not extend across it as the Petalodonts do. Sargus lives in the waters on the coast of Madagascar, and its spatulate teeth are admirably adapted for seizing molluses like the limpet which adhere strongly to the rock or other substance on which they exist. The resemblance may at least indicate a parallel in the food of the two genera.

Pristodus falcatus, Agassiz, occurs frequently in the upper beds of the limestone series of Yorkshire. A single tooth appears to have enveloped the whole of the upper or lower jaw to which it was attached, and extended along the palate and floor of the mouth inwards, so that the two teeth fit each other. The external edge envelopes the jaws, that of the upper jaw being extended downwards so as to considerably overlap the lower one. The 
extended edge forms a cutting surface which is toothed like a saw with the largest denticles in front and gradually diminishing in size backwards. The tooth of the lower jaw is devoid of denticles; it is raised in the centre of the external edge in the form of a single point, which fits a corresponding hollow inside the margin of the upper tooth. The pair of teeth present a resemblance to the beaks of a parrot, in the manner in which they fit to each other.

Amongst the fishes of the primary or secondary rocks there is no other genus known which approaches in form and character to Pristodus. Amongst living fishes the Diodonts offer a somewhat close resemblance to it. Diodon is an inhabitant of tropical seas ; the fishes are sometimes called "sea hedgehogs," they are covered with a thick skin without scales, over which are distributed a large number of spines. They have the power of inflating the body, and assuming a globular form their spines become extended, like those of a hedgehog. Their jaws consist of a single undivided plate, and are admirably adapted for breaking off branches of corals, from which they principally obtain their food. Fossil remains of Diodon have been found in the tertiary limestones of Monte Bolca. The Pristodus of the Carboniferous Limestone agrees with the recent Gymnodont Diodon in its dentition, but there in all probability the resemblance ended. The recent fish has a bony skeleton and is covered with bony spines, the fossil was apparently cartilaginous, and no spines have been found which at all resemble those of Diodon. It is very likely that the similarity of the dentition may indicate a similarity of diet, the remains of coral are abundant in the limestone.

In addition to the genera of fossil fish-remains already mentioned and which have been previously described, there are others which have not received the same attention, but these in all probability may be included in one or other groups, already indicated. The peculiar spines, Cladacanthus and Physonemus, 
occur sparingly in the Limestone of Wensleydale. The relationship of these peculiar ichthyodoralites is little understood.

In conclusion-it may be drawn from previous observations, that the fishes occurring most frequently in the thick-bedded lower limestone of other parts of the British Islands are absent or only represented by dwarfed specimens. The great spines of Ctenacanthus and Oracanthus are not present. The great teeth of Orodus, most of the genera of the Cochliodonts, the large palates of Psammodus, and the teeth of the Petalodonts, have in each case become dwarfed and comparatively insignificant. They present the appearance of groups which have previously reached the climax of their existence and were gradually succumbing to a more or less unfavourable environment-with the advent of the coal measures they have almost entirely disappeared.

ON THE LEAD VEINS IN THE NEIGHBOURHOOD OF SKIPTON.

BY J. RAY EDDY, F.G.S.

BeFone directing attention especially to the subject of my paper, it is due to the Members to explain that it was first proposed that the Lead Veins in the Grit-beds of Craven should be considered, but ultimately the veins described by the present title were preferred. This shange practically leaves me a somewhat barren subject, because the Cononley Lead Mine has been entirely abandoned for several years in the eastern part, and almost so in the western, and it is the only place near Skipton, where the regular working of a vein has been carried on.

A paper on the larger and much more interesting Mining field in Wharfedale may prove welcome on some future occasion when you may be inclined to extend your excursions to that district.

The main vein is part of a large "fault," the throw of which has never been truly ascertained by the miner, partly because the sides have been rarely seen, and further on account of the disturbed 